\title{
Studies on Infant Diarrhea. II. Absorption of Glucose and Net Fluxes of Water and Sodium Chloride in a Segment of the Jejunum*
}

\author{
R. Torres-Pinedo, $\dagger$ C. L. Rivera, $\$$ and S. Fernández $\ddagger$ With the technical \\ assistance of M. Maldonado \\ (From the General Clinical Research Center, the Department of Pediatrics of the School of \\ Medicine, and the University Hospital, University of Puerto Rico, San Juan,
}

Puerto Rico)

Increased stool losses of water, solute, and organic acids after the ingestion of milk during acute diarrhea of infancy have been related to impaired absorption of carbohydrate (1). We have observed that the osmolality of diarrheal stool water is usually high during periods of milk intake. Furthermore, we have demonstrated that carbohydrate comprises most of the solute content of the stool water and that there exists a reciprocal relationship between the concentration of this compound and that of $\mathrm{Cl}^{-}, \mathrm{Na}^{+}$, and $\mathrm{K}^{+}$. On the other hand, there is a direct relationship between the concentration of carbohydrate and total organic anions. Similar effects of carbohydrate on stool volume and acidity have been described when specific disaccharidases are deficient (2-9) or when monosaccharide absorption is impaired (10 13). An obvious assumption is that unabsorbed carbohydrate exerts an osmotic effect in the bowel and constitutes substrate for the generation of organic acids. However, studies directed at verifying these assumptions and determining the characteristics of these processes at different levels of the small and large bowel have not been performed. Our present studies demonstrate that the absorption of glucose by the jejunum is impaired in acute diarrhea of infancy. The studies also show that the associated net movement of fluid into

* Submitted for publication March 9, 1966; accepted September 7, 1966.

Supported by grants FR-63-04 from the Division of Research Facilities and Resources, U. S. Public Health Service, and AM 07595-03 from the National Institute of Arthritis and Metabolic Diseases.

$\dagger$ Address requests for reprints to Dr. R. TorresPinedo, General Clinical Research Center, School of Medicine, University of Puerto Rico, San Juan, P. R.

$\$$ Research fellow supported by grant 1-S01-FR-0511903 from the National Institutes of Health. the bowel in diarrhea occurs as a consequence of bulk flow, determined by excesses of glucose in the bowel lumen.

\section{Methods}

Ten infants with acute diarrhea ( 1 to 3 days' duration) who were passing liquid stools at the time they were chosen for study were investigated. In five of these, a pathogenic Escherichia coli was isolated from the stools. All were taking milk without vomiting. Once they had recovered, no recurrence of the disease was observed on follow-up examination. Seven infants who had had urinary tract infections, but who had received no medication for at least 1 month, constituted the control group. All infants were 2 to 4 months old and weighed between 4 and $6 \mathrm{~kg}$.

The infants were given only small quantities of water orally after 2:00 a.m. of the day of the study. Oral intubation of the bowel with polyethylene tubing was begun at 6:00 a.m. The tubes (Figure 1) were gently inserted through a pacifier into the stomach and allowed to progress into the bowel by gravity and peristalsis. Placement in the jejunum was verified by a spot film after bile-tinged fluid had begun to flow from the proximal tube (Figure 1, A). The design and placement of the tube permitted study of net fluxes in a $25-\mathrm{cm}$ segment of jejunum. The proximal orifice (A), through which test solutions were infused, was positioned in the vicinity of the ligament of Treitz, thus placing orifices B and C 15 and $40 \mathrm{~cm}$ into the

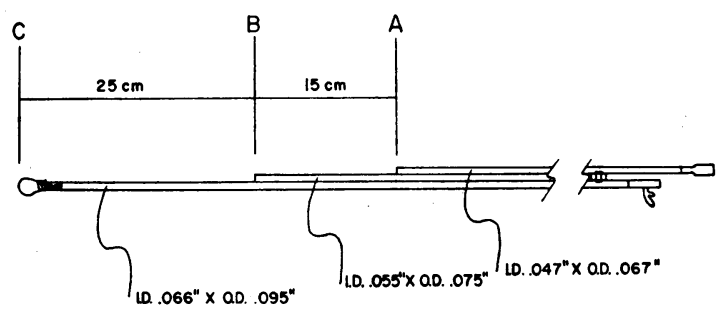

Fig. 1. Polyvinyl tubing system USEd in Perfusion OF THE JEJUNUM. Infusions were administered through opening A. Fluid was collected through openings B and $\mathrm{C}$. 
TABLE I

Volume and composition of solutions infused into the jejunum*

\begin{tabular}{|c|c|c|c|c|c|c|c|}
\hline Infusiont & & Volume & Inulin & Glucoset & $\mathrm{Na}^{+}$ & $\mathrm{Cl}^{-}$ & Osmolalit \\
\hline 1 & $\begin{array}{l}\text { Mean } \\
\text { SD }\end{array}$ & $\begin{array}{c}m l / m i n \\
1.16 \\
(0.04)\end{array}$ & $\begin{array}{l}\mathrm{mg} / \mathrm{ml} \\
12.2 \\
(0.9)\end{array}$ & $\begin{array}{c}\text { Mmoles } / m l \\
0\end{array}$ & $\begin{array}{c}\text { umoles } / \mathrm{ml} \\
156 \\
\text { (1) }\end{array}$ & 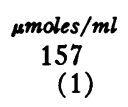 & $\begin{array}{c}\mu O s m / g \\
302\end{array}$ \\
\hline 2 & $\begin{array}{l}\text { Mean } \\
\text { SD }\end{array}$ & $\begin{array}{c}1.14 \\
(0.01)\end{array}$ & $\begin{array}{l}12.4 \\
(0.2)\end{array}$ & $\begin{array}{l}478 \\
(16)\end{array}$ & $\begin{array}{l}157 \\
(1)\end{array}$ & $\begin{array}{l}158 \\
(1)\end{array}$ & 811 \\
\hline 3 & $\begin{array}{l}\text { Mean } \\
\text { SD }\end{array}$ & $\begin{array}{c}1.15 \\
(0.02)\end{array}$ & $\begin{array}{l}12.7 \\
(0.2)\end{array}$ & $\begin{array}{l}911 \\
(44)\end{array}$ & $\begin{array}{r}150 \\
-\quad(1)\end{array}$ & $\begin{array}{l}150 \\
\text { (1) }\end{array}$ & 1,290 \\
\hline
\end{tabular}

* Results of these perfusions are given in Tables II and III.

$\dagger$ Each infusion was administered during 80 minutes of equilibration followed by three 20 -minute test periods.

$\ddagger$ A chemically pure, anhydrous $\alpha-\mathrm{D}(+)$-glucose was used in the preparation of these solutions.

jejunum, respectively. The position of the tubes was checked by another spot film after completion of the study. In all experiments, the distance between the distal orifice (C) and the lips was 70 to $80 \mathrm{~cm} .^{1}$

The flow rate and composition of the three saline and glucose-saline solutions infused into the jejuna of seven infants with diarrhea and seven normal infants are shown in Table I. A constant infusion pump was used to administer the solutions at a rate of $1.16 \mathrm{ml}$ per minute. During an equilibration phase for each solution, consecutive samples were collected at 10 - to 15-minute intervals from the distal orifice (C), until little variation in the concentration of the nonabsorbable marker (inulin) was observed,

1 The average length of the small bowel measured at autopsy in five infants of $2 \frac{1}{2}$ to $5 \mathrm{~kg}$ of body weight was $220 \mathrm{~cm}$. This is a rough approximation, since measurement of the physiological bowel length requires special techniques (14) that were not followed in our study. usually after 80 to 90 minutes. After equilibration had been established, fluid was collected from the distal orifice for three successive 20-minute test periods. Midway during each test period, $1 \mathrm{ml}$ of fluid was sampled from tube $B$ (the initial $1 \mathrm{ml}$ obtained was discarded to avoid errors caused by the dead space). Since the mean variation in the concentration of inulin in consecutive test periods at the proximal collecting site $( \pm 5 \%)$ did not differ significantly from the variation observed at the distal point $( \pm 4 \%)$ where fluid was collected continuously, we assumed that changes of the observed concentrations during each test period had no major effect on our results, even though midpoint samples were not representative of all the fluid passing the proximal collecting site.

In three additional studies in patients, the infusion rate was increased to $3.2 \mathrm{ml}$ per minute, and fluid was obtained continuously from both collecting tubes. The flow of fluid through tube B was controlled with a screw clamp

TABLE II

Composition of perfusion fluid at proximal and distal collecting points of the jejunum

\begin{tabular}{|c|c|c|c|c|c|c|c|c|c|c|c|c|c|}
\hline \multirow[b]{2}{*}{ Group } & \multirow{2}{*}{$\begin{array}{c}\text { No. of } \\
\text { subjects }\end{array}$} & \multirow{2}{*}{$\begin{array}{l}\text { Study } \\
\text { period* }\end{array}$} & & \multicolumn{2}{|c|}{ Inulin } & \multicolumn{2}{|c|}{ Glucose } & \multicolumn{2}{|c|}{$\mathrm{Cl}^{-}$} & \multicolumn{2}{|c|}{$\mathrm{Na}^{+}$} & \multicolumn{2}{|c|}{ Osmolality } \\
\hline & & & & Proximal & Distal & Proximal & Distal & Proximal & Distal & Proximal & Distal & Proximal & Distal \\
\hline & & & & $m g / s$ & & umoles & $/ m l$ & umoles & $/ m l$ & 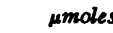 & $/ m l$ & $\mu O s m$ & $/ g$ \\
\hline \multirow[t]{3}{*}{ Control } & 7 & 1 & $\begin{array}{l}\text { Mean } \\
\text { SD }\end{array}$ & $\begin{array}{c}8.2 \\
(0.1)\end{array}$ & $\begin{array}{c}8.9 \\
(0.6)\end{array}$ & & & $\begin{array}{c}139 \\
(3)\end{array}$ & $\begin{array}{c}139 \\
(3)\end{array}$ & $\begin{array}{r}141 \\
(2)\end{array}$ & $\begin{array}{c}136 \\
(1)\end{array}$ & $\begin{array}{r}292 \\
(5)\end{array}$ & $\begin{array}{r}289 \\
(3)\end{array}$ \\
\hline & & 2 & $\begin{array}{l}\text { Mean } \\
\text { SD }\end{array}$ & $\begin{array}{c}5.5 \\
(0.5)\end{array}$ & $\begin{array}{l}12.5 \\
(2.5)\end{array}$ & $\begin{array}{l}150 \\
(16)\end{array}$ & $\begin{array}{c}36 \\
(34)\end{array}$ & $\begin{array}{l}95 \\
(3)\end{array}$ & $\begin{array}{l}120 \\
(12)\end{array}$ & $\begin{array}{l}97 \\
(5)\end{array}$ & $\begin{array}{l}114 \\
(16)\end{array}$ & $\begin{array}{c}354 \\
(8)\end{array}$ & $\begin{array}{c}293 \\
(6)\end{array}$ \\
\hline & & 3 & $\begin{array}{l}\text { Mean } \\
\text { SD }\end{array}$ & $\begin{array}{c}4.0 \\
(0.4)\end{array}$ & $\begin{array}{c}3.7 \\
(0.4)\end{array}$ & $\begin{array}{l}238 \\
(22)\end{array}$ & $\begin{array}{l}142 \\
(31)\end{array}$ & $\begin{array}{l}77 \\
(3)\end{array}$ & $\begin{array}{l}70 \\
(4)\end{array}$ & $\begin{array}{l}77 \\
(4)\end{array}$ & $\begin{array}{l}69 \\
(5)\end{array}$ & $\begin{array}{c}438 \\
(5)\end{array}$ & $\begin{array}{l}315 \\
(22)\end{array}$ \\
\hline \multirow[t]{3}{*}{ Diarrhea } & 7 & 1 & $\begin{array}{l}\text { Mean } \\
\text { SD }\end{array}$ & $\begin{array}{c}7.5 \\
(1.3)\end{array}$ & $\begin{array}{c}8.3 \\
(1.7)\end{array}$ & & & $\begin{array}{c}140 \\
(3)\end{array}$ & $\begin{array}{r}137 \\
(2)\end{array}$ & $\begin{array}{c}140 \\
(2)\end{array}$ & $\begin{array}{c}136 \\
(1)\end{array}$ & $\begin{array}{c}284 \\
(3)\end{array}$ & $\begin{array}{r}284 \\
(7)\end{array}$ \\
\hline & & 2 & $\begin{array}{l}\text { Mean } \\
\text { SD }\end{array}$ & $\begin{array}{c}5.3 \\
(1.1)\end{array}$ & $\begin{array}{c}5.4 \\
(1.0)\end{array}$ & $\begin{array}{l}161 \\
(41)\end{array}$ & $\begin{array}{l}104 \\
(17)\end{array}$ & $\begin{array}{l}84 \\
(2)\end{array}$ & $\begin{array}{l}84 \\
(9)\end{array}$ & $\begin{array}{l}87 \\
(5)\end{array}$ & $\begin{array}{l}87 \\
(8)\end{array}$ & $\begin{array}{l}357 \\
(20)\end{array}$ & $\begin{array}{c}289 \\
(3)\end{array}$ \\
\hline & & 3 & $\begin{array}{l}\text { Mean } \\
\text { SD }\end{array}$ & $\begin{array}{c}4.1 \\
(0.4)\end{array}$ & $\begin{array}{c}3.2 \\
(0.2)\end{array}$ & $\begin{array}{l}261 \\
(19)\end{array}$ & $\begin{array}{l}169 \\
(17)\end{array}$ & $\begin{array}{l}69 \\
(9)\end{array}$ & $\begin{array}{l}61 \\
(7)\end{array}$ & $\begin{array}{l}69 \\
(8)\end{array}$ & $\begin{array}{l}65 \\
(6)\end{array}$ & $\begin{array}{l}430 \\
(20)\end{array}$ & $\begin{array}{l}333 \\
(38)\end{array}$ \\
\hline
\end{tabular}

\footnotetext{
* Rate and composition of solutions perfused during periods 1,2 , and 3 are given in Table I.
} 
TABLE III

Comparison of the net fluxes of water, glucose, sodium, chloride, and total solute in and out of the jejunum in control infants and infants with acute diarrhea

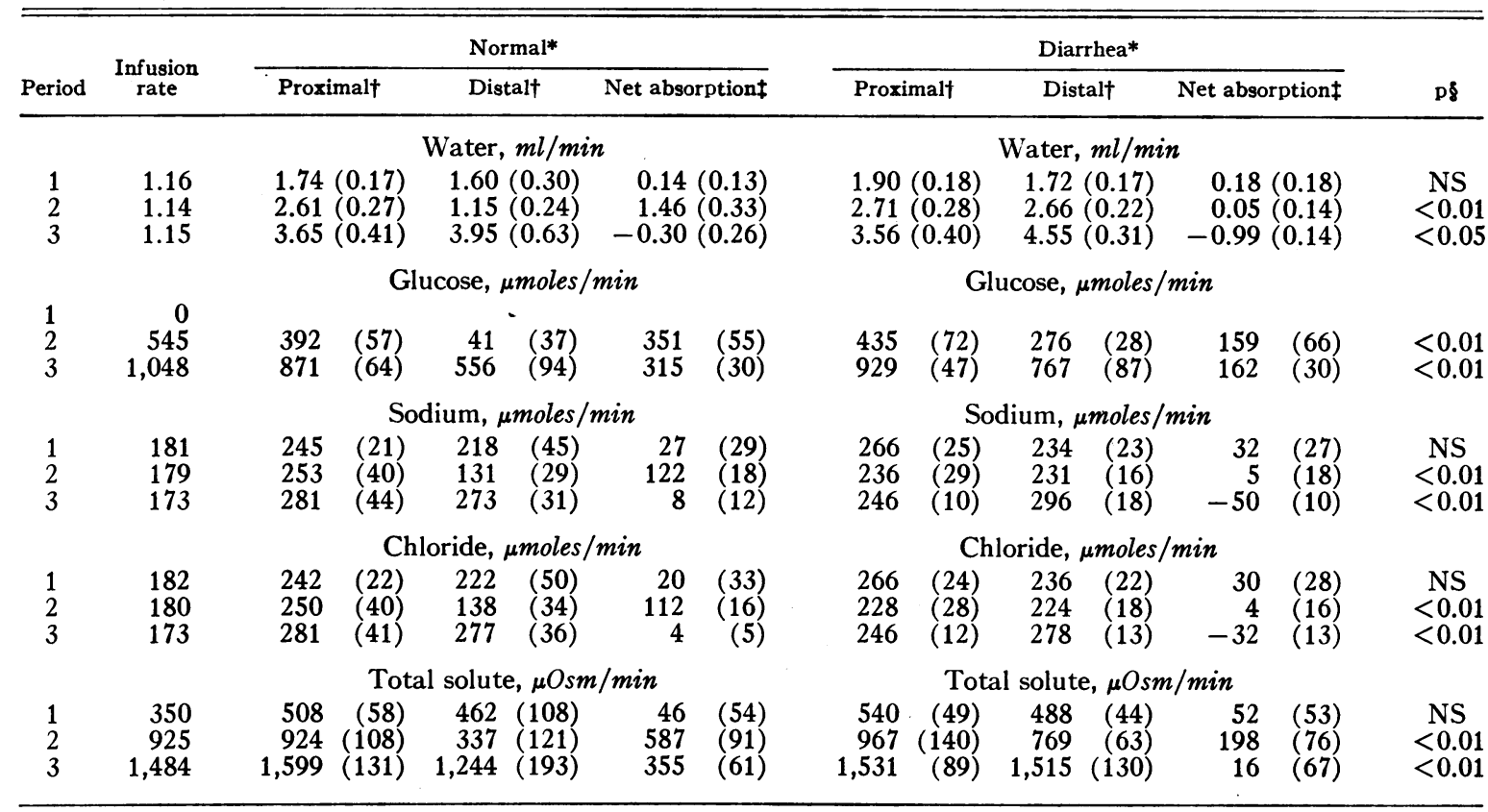

* The seven normal infants and the seven infants with acute diarrhea were similar in age and body weight.

† Values at proximal and distal collecting points were derived from data given in Table II. Numbers in parentheses represent standard deviations.

$\ddagger$ Net movement out of lumen. Net movement into lumen is expressed as (-).

$\S$ Significance of differences between both groups. $N S=$ not significant $(p>0.1)$.

so that approximately $5 \mathrm{ml}$ was collected each 15 -minute period. The concentrations of $\mathrm{NaCl}$ in the solutions infused were approximately those used in the other studies, but the glucose concentrations, and thus the osmolalities, were lower. Polyethylene glycol $(1 \%)$ was used as the nonabsorbable marker.

Inulin was determined in an autoanalyzer by the method of Roe, Epstein, and Goldstein (15), polyethylene glycol by the method of Hydén (16), glucose by a glucoseoxidase method (17), sodium by flame photometry in an autoanalyzer, chloride in a Cotlove chloridometer, and osmolality by the freezing point-depression technique.

Calculations. The method used to calculate net water, ions, and glucose fluxes was recently described by Fordtran and co-workers (18). Calculations were based upon differences in the composition of perfusate between proximal (B) and distal (C) collecting points as follows: $\mathrm{V}_{\mathbf{B}}=\mathrm{V}_{\mathbf{A}} \cdot\left([\mathrm{In}]_{\mathbf{A}} /[\operatorname{In}]_{\mathbf{B}}\right) ; \mathrm{V}_{\mathbf{C}}=\mathrm{V}_{\mathbf{B}} \cdot\left([\operatorname{In}]_{\mathbf{B}} /[\operatorname{In}]_{\mathbf{C}}\right)-\mathrm{S}_{\mathbf{B}}$; net water flux (milliliters per minute) $=V_{B}-V_{C}$; and net ions and glucose fluxes $=\mathrm{V}_{\mathrm{B}} \cdot[\mathrm{X}]_{\mathrm{B}}-\mathrm{V}_{\mathrm{C}} \cdot[\mathrm{X}]_{\mathrm{C}}$. $\mathrm{V}_{\mathrm{A}}$ $=$ infusion rate (milliliters per minute); $\mathrm{V}_{\mathrm{B}}=$ flow rate at proximal collecting point (milliliters per minute); $V_{0}$ = flow rate at distal collecting point (milliliters per minute); $[\mathrm{In}]_{\Delta}=$ inulin concentration of infusate (milligrams per milliliter); $[\mathrm{In}]_{\mathbf{B}}=$ inulin concentration at proximal collecting point; [In $]_{\mathrm{c}}=$ inulin concentration at distal point $;[\mathrm{X}]_{\mathrm{B}}$ and $[\mathrm{X}]_{\mathrm{C}}=$ concentrations of ions and glu- cose at proximal and distal collecting points; $\mathrm{S}_{\mathbf{B}}=$ sample collected at $B$ (milliliters per minute). A positive sign indicates net movement out of the lumen and a negative sign net movement into the lumen.

\section{Results}

Complete data in seven normal infants and seven infants with acute diarrhea are given in Table II. Derived values for both groups are presented in Table III.

Glucose absorption in the test jejunal segment. Table III shows that the average maximal rate of glucose absorption in normal infants was 351 $\mu$ moles per minute as compared with $159 \mu$ moles in infants with diarrhea. In the control studies the glucose load during period 2 only slightly exceeded the maximal absorptive capacity of the test segment, but in the patients with diarrhea comparable loads were always far above the absorptive capacity, and a large proportion of glucose remained unabsorbed. In neither group did the rate of absorption increase during period 3 despite large increases in the concentration and load of 

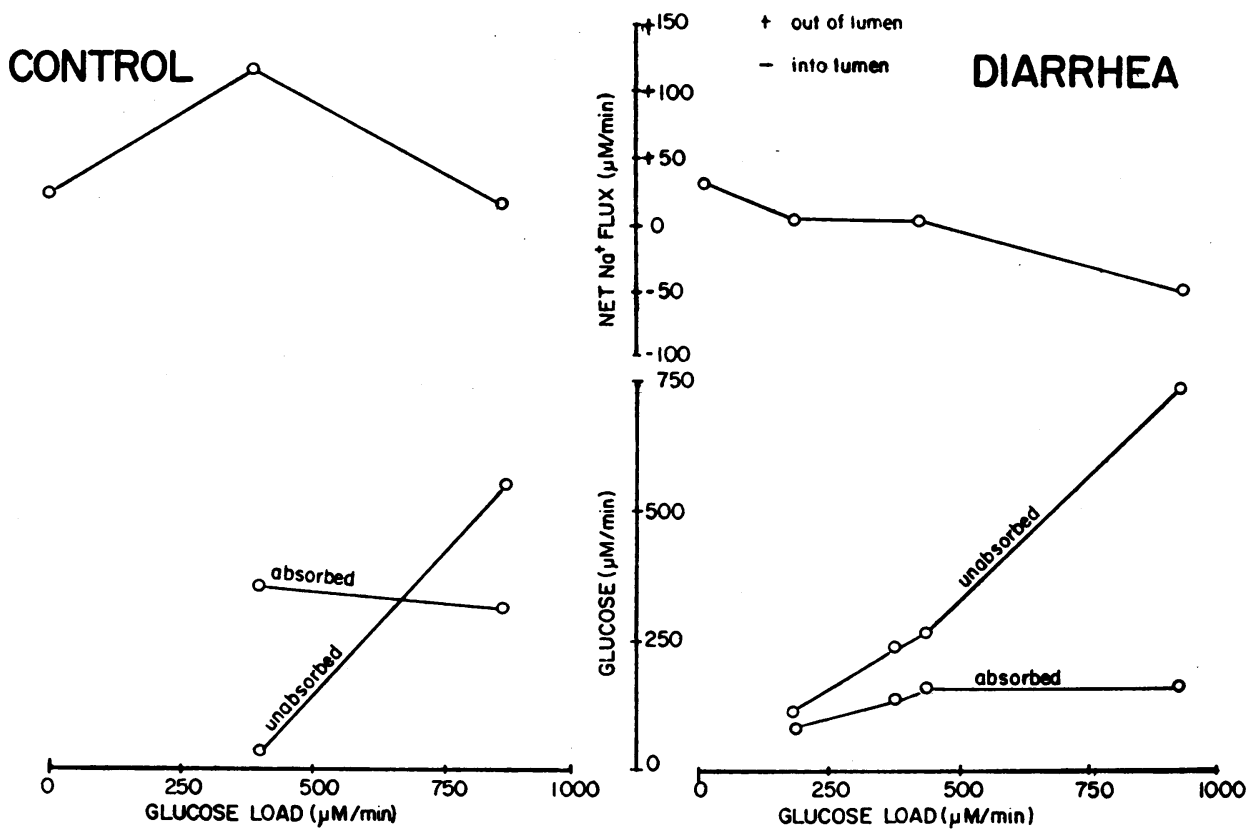

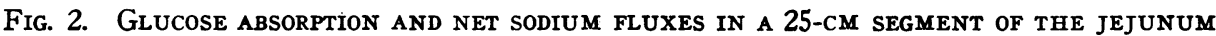
OF NORMAL INFANTS AND INFANTS WITH DIARRHEA. In normal infants absorption of sodium was maximal as the glucose load coincided with the maximal rate of glucose absorption. Saturation of glucose absorptive capacity resulted in marked decreases of the net sodium transfer out of the lumen. In diarrhea, saturation of the absorptive capacity for glucose and effect on sodium transfer occurred at lower glucose loads. See Tables III and V for details.

glucose. Thus, the quantity of glucose unabsorbed increased in proportion to the load and was always significantly greater in patients with diarrhea than in control infants.

Net water and ion fluxes. Table III shows that the flow rate of water at the proximal collecting site was greater than the infusion rate. The magnitude of the volume increment was largely determined by the concentration of glucose in the perfusion fluid, since a very rapid dilution of this fluid occurred in the first $15-\mathrm{cm}$ segment (between points $\mathrm{A}$ and $\mathrm{B}$ ).

TABLE IV

Composition of perfusion fluid at proximal and distal collecting points of the jejunum in three infants with acute diarrhea*

\begin{tabular}{|c|c|c|c|c|c|c|c|c|c|c|c|}
\hline \multirow[b]{2}{*}{ Period } & & \multicolumn{2}{|c|}{ PEG } & \multicolumn{2}{|c|}{ Glucose } & \multicolumn{2}{|c|}{$\mathrm{Na}^{+}$} & \multicolumn{2}{|c|}{$\mathrm{Cl}^{-}$} & \multicolumn{2}{|c|}{ Osmolality } \\
\hline & & Proximalt & Distal† & Proximal† & Distal + & Proximalt & Distal† & Proximal† & Distalt & Proximalt & Distalt \\
\hline & & \multicolumn{2}{|c|}{$m g / m l$} & \multicolumn{2}{|c|}{ umoles $/ \mathrm{ml}$} & \multicolumn{2}{|c|}{ umoles $/ \mathrm{ml}$} & \multicolumn{2}{|c|}{ Amoles $/ m l$} & \multicolumn{2}{|c|}{$\mu O s m / g$} \\
\hline 1 & $\begin{array}{l}\text { Mean } \\
\text { SD }\end{array}$ & $\begin{array}{l}9.2 \\
(0.3)\end{array}$ & $\begin{array}{c}9.1 \\
(0.1)\end{array}$ & & & $\begin{array}{c}146 \\
(2)\end{array}$ & $\begin{array}{c}144 \\
(2)\end{array}$ & $\begin{array}{r}146 \\
(1)\end{array}$ & $\begin{array}{l}144 \\
(1)\end{array}$ & $\begin{array}{l}279 \\
(1)\end{array}$ & $\begin{array}{c}278 \\
(2)\end{array}$ \\
\hline 2 & $\begin{array}{l}\text { Mean } \\
\text { SD }\end{array}$ & $\begin{array}{c}9.5 \\
(0.3)\end{array}$ & $\begin{array}{c}9.5 \\
(0.1)\end{array}$ & $\begin{array}{l}64 \\
(6)\end{array}$ & $\begin{array}{c}35 \\
(10)\end{array}$ & $\begin{array}{c}128 \\
(4)\end{array}$ & $\begin{array}{r}127 \\
(5)\end{array}$ & $\begin{array}{c}128 \\
(4)\end{array}$ & $\begin{array}{c}128 \\
(5)\end{array}$ & $\begin{array}{c}315 \\
(6)\end{array}$ & $\begin{array}{c}286 \\
(3)\end{array}$ \\
\hline 3 & $\begin{array}{l}\text { Mean } \\
\text { SD }\end{array}$ & $\begin{array}{c}8.5 \\
(0.1)\end{array}$ & $\begin{array}{c}8.8 \\
(0.6)\end{array}$ & $\begin{array}{l}116 \\
(12)\end{array}$ & $\begin{array}{c}74 \\
(18)\end{array}$ & $\begin{array}{r}114 \\
(1)\end{array}$ & $\begin{array}{c}110 \\
(6)\end{array}$ & $\begin{array}{c}110 \\
(2)\end{array}$ & $\begin{array}{c}110 \\
(7)\end{array}$ & $\begin{array}{c}351 \\
(5)\end{array}$ & $\begin{array}{c}299 \\
(5)\end{array}$ \\
\hline
\end{tabular}

* Volume and composition of fluid perfused in these studies were as follows: period 1, volume, $3.2 \mathrm{ml}$ per minute; polyethylene glycol, $10 \mathrm{mg}$ per $\mathrm{ml} ; \mathrm{NaCl}, 155 \mathrm{mEq}$ per L; osmolality, $276 \mathrm{mOsm}$ per $\mathrm{kg}$; period 2 , volume, $3.2 \mathrm{ml}$ per minute; polyethylene glycol, $9.7 \mathrm{mg}$ per $\mathrm{ml} ; \mathrm{NaCl}, 153 \mathrm{mEq}$ per L; glucose, $101 \mathrm{mmoles}$ per L; osmolality, $382 \mathrm{mOsm}$ per $\mathrm{kg}$; period 3, volume, $3.2 \mathrm{ml}$ per minute; polyethylene glycol, $10 \mathrm{mg}$ per $\mathrm{ml} ; \mathrm{NaCl}, 151 \mathrm{mEq}$ per L; glucose, $187 \mathrm{mmoles}$ per L; osmolality, $473 \mathrm{mOsm}$ per $\mathrm{kg}$.

† Fluid was collected at a constant flow from both collecting points. 
TABLE V

Net fluxes of water, glucose, and electrolytes in three infants with acute diarrhea*

\begin{tabular}{|c|c|c|c|c|c|c|}
\hline Period & \multicolumn{2}{|c|}{ Proximal } & \multicolumn{2}{|c|}{ Distal } & \multicolumn{2}{|c|}{ Net absorption } \\
\hline \multicolumn{7}{|c|}{ Water, $m l / m i n$} \\
\hline 1 & \multicolumn{2}{|c|}{$3.15(0.16)$} & \multicolumn{2}{|c|}{$3.18(0.06)$} & \multicolumn{2}{|c|}{$-0.03(0.09)$} \\
\hline 2 & \multicolumn{2}{|c|}{$3.00(0.14)$} & \multicolumn{2}{|c|}{$3.00(0.04)$} & \multicolumn{2}{|c|}{$0(0.15)$} \\
\hline 3 & \multicolumn{2}{|c|}{$3.37(0.03)$} & \multicolumn{2}{|c|}{$3.27(0.27)$} & \multicolumn{2}{|c|}{$0.10(0.29)$} \\
\hline \multicolumn{7}{|c|}{ Glucose, $\mu$ moles $/$ min } \\
\hline 1 & 0 & & 0 & & 0 & \\
\hline 2 & 192 & (9) & 105 & $(25)$ & 87 & (15) \\
\hline 3 & 391 & (36) & 242 & $(68)$ & 149 & (36) \\
\hline \multicolumn{7}{|c|}{$\mathrm{Na}^{+}, \mu$ moles $/ \min$} \\
\hline 1 & 460 & (27) & 458 & (9) & 2 & (20) \\
\hline 2 & 384 & (13) & 381 & (13) & 3 & (1) \\
\hline 3 & 384 & (5) & 360 & (12) & 24 & (17) \\
\hline \multicolumn{7}{|c|}{$\mathrm{Cl}^{-}, \mu$ moles $/ \min$} \\
\hline 1 & 460 & (22) & 458 & (7) & 2 & (18) \\
\hline 2 & 384 & (15) & 384 & (16) & 0 & (1) \\
\hline 3 & 371 & $(8)$ & 360 & (6) & 11 & (11) \\
\hline \multicolumn{7}{|c|}{ Total solute, $\mu O \mathrm{sm} / \mathrm{min}$} \\
\hline 1 & 879 & (40) & 884 & (12) & -5 & (31) \\
\hline 2 & 945 & (32) & 858 & (19) & 87 & (25) \\
\hline 3 & 1,183 & (14) & 978 & (92) & 205 & (89) \\
\hline
\end{tabular}

* Calculated from values given in Table IV. Numbers in parentheses represent standard deviations of the mean.

Similar low rates of water and salt absorption in the test segment were observed in patients and control infants during infusion of saline alone (period 1). Addition of glucose effected changes in net transport of water and $\mathrm{NaCl}$ that were different in the two groups. In normal infants, a glucose load close to the maximal absorptive capacity of the test segment induced marked increments in net water, $\mathrm{Na}^{+}$, and $\mathrm{Cl}^{-}$absorption (period 2). This effect disappeared when the glucose load was increased, and large amounts of glucose remained unabsorbed (period 3). A fall in $\mathrm{Na}^{+}$and $\mathrm{Cl}^{-}$absorption and a net flux of water into the bowel lumen occurred in this last period. A comparison of the effects of absorbed and unabsorbed glucose on net $\mathrm{Na}^{+}$transfer in normal infants and infants with diarrhea is illustrated in Figure 2. In cases of diarrhea, the larger amounts of unabsorbed sugar caused a progressive decrease in $\mathrm{Na}^{+}$absorption until a reversal of the net transfer of the ion occurred with the higher glucose loads. The effect of glucose on net water transfer paralleled that on $\mathrm{Na}^{+}$(Table III).

In the studies shown in Tables IV and V, the perfusion rate and the concentration of glucose in the perfusate were adjusted to obtain glucose loads near the maximal absorptive capacity observed in the first seven infants with diarrhea.
This was done to determine whether $\mathrm{Na}^{+}$absorption would be enhanced in diarrhea when absorption of the sugar was nearly complete, thus eliminating the unfavorable osmotic gradient created by unabsorbed glucose. The composition of the fluid passing the sampling sites is shown in Table IV. Glucose concentrations were lower and $\mathrm{NaCl}$ concentrations higher than in the previous studies. Table $\mathrm{V}$ shows that glucose absorption in the segment did not reach the maximal rate of absorption with lower concentrations of glucose (period 2 ), and net $\mathrm{Na}^{+}$transfer did not increase.

Net solute transfer. The osmolalities of the fluid infused (Table I) were markedly decreased at the proximal collecting site (Table II) and tended to fall within the range of osmolalities of the body fluids at the distal collecting point. Dilution of the luminal fluid was accomplished by net absorption of solute and bulk flow of fluid into the bowel (Table III). Average maximal rate of net solute transfer in normal infants was 587 $\mu$ Osm per minute as compared with $198 \mu \mathrm{Osm}$ in infants with diarrhea (period 2). Conversely, net water transfer into the bowel was $0.30 \mathrm{ml}$ per minute in normal infants and $0.99 \mathrm{ml}$ per minute in infants with diarrhea (period 3).

\section{Discussion}

The present observations demonstrate that glucose absorption in the proximal jejunum is impaired in acute diarrhea of infancy. Although the factors responsible for this impairment cannot be defined, some immediate consequences of the disturbed glucose absorption are apparent and derive from the physiological response of the small bowel to osmotic pressure gradients. Absorbed or unabsorbed glucose draws fluid in bulk out of or into the small bowel. The concentration of $\mathrm{NaCl}$ in the fluid moving in bulk depends largely upon the reflection coefficient $(\sigma)$ for $\mathrm{NaCl}^{2}$ Fordtran and co-workers (18) have found a value of 0.45 for $\sigma \mathrm{NaCl}$ in the upper jejunum of adults. If this value were applied to our normal infants, the in-

2 The Staverman reflection coefficient (19) was originally applied to the transfer of nonelectrolytes through membranes. Extension of this coefficient to the transport of salts across biological membranes must take into consideration the effect of electrical potentials on the individual ions of the salt (20). 
crease in $\mathrm{NaCl}$ absorption effected by glucose would be largely determined by solvent drag. ${ }^{3}$

When fluid entering the small intestine is hyperosmolal to plasma, there is rapid filtration of water until the luminal fluid becomes isosmolal. If luminal $\left[\mathrm{Na}^{+}\right]$is initially equal to plasma $\left[\mathrm{Na}^{+}\right]$, the magnitude of the decrease in the luminal concentration of the ion depends upon the quantities of other electrolytes and nonelectrolytes contributing to the osmolality and upon the permeability of the gut wall to these substances. Therefore, with increasing concentrations of other solutes the concentration of $\mathrm{Na}^{+}$approaches that of the fluid flowing in bulk into the bowel under the influence of an osmotic gradient. Hence, the limiting factor to the dilution of luminal $\mathrm{Na}^{+}$achieved by that mechanism is the reflection coefficient for $\mathrm{Na}^{+}$ at each level of the bowel. The mean lower concentration of $\mathrm{Na}^{+}$in luminal fluid observed in normal infants was $69 \mathrm{mEq}$ per $\mathrm{L}$, when the mean plasma $\mathrm{Na}^{+}$was $135 \mathrm{mEq}$ per $\mathrm{L}$. The value was, therefore, close to that predicted for a reflection coefficient of 0.45 .

A brief surge of hyperosmolality created by perfusion with an absorbable nonelectrolyte, such as glucose, causes a transient dilution of luminal $\mathrm{Na}^{+}$ by bulk flow effect and thus establishes a chemical gradient between lumen and blood. However, in the normal infant, glucose and water are rapidly absorbed, and again the concentration of $\mathrm{Na}^{+}$in the absorbate is less than in the parent fluid. Hence, the $\mathrm{Na}^{+}$gradient diminishes, and adsorption of this element by mechanisms other than solvent drag is facilitated. The basis for these assertions was first established by Abbott, Karr, and Miller (22), who showed an inverse relation between glucose and $\mathrm{Cl}^{-}$concentrations in jejunal and ileal fluids of adults after oral loads of hypertonic glucose.

Our studies demonstrate that saturation of the absorptive capacity of the jejunum for glucose results in decreasing rates of fluid and $\mathrm{NaCl}$ uptake in normal infants and infants with diarrhea. The mechanism operates in normal and diseased bowel, but the larger amounts of unabsorbed glucose in

\footnotetext{
${ }^{3}$ Calculated from the following equation: $\mathrm{J}_{\mathrm{NaCl}}=\mathrm{C}_{\mathrm{NaCl}}$ $\left(1-\sigma_{\mathrm{NaCl}}\right) J_{V}$, where $\mathrm{J}_{\mathrm{NaOl}}=$ rate of $\mathrm{NaCl}$ transfer due to solvent drag, $\mathrm{C}_{\mathrm{NaOl}}=$ mean $\mathrm{NaCl}$ concentration in the luminal fluid calculated according to Fordtran and coworkers (18), and $\mathrm{J}_{\nabla}=$ net flux of solvent (21).
}

diarrheal disease create an unfavorable balance in net flow of fluid across the jejunum. As a result, there is augmented delivery of glucose and fluid of decreasing ionic concentrations to distal segments of the bowel. Since absorption of water in lower segments depends increasingly upon absorption of $\mathrm{Na}^{+}$, it is evident that the rate of fluid absorption will change reciprocally with the $\mathrm{Na}^{+}$gradient. Curran and Schwartz (23) have shown that water absorption ceases in the rat colon when the luminal $\mathrm{Na}^{+}$concentration is below $75 \mathrm{mEq}$ per $\mathrm{L}$; mannitol was the nonabsorbable solute that made the solutions isosmolal with plasma.

It is likely that in diarrheal disease of infancy, impaired absorption of glucose (or other sugars) leads to a marked decrease in the ability of the bowel to absorb salt and water. In fact, we have demonstrated in previous studies $(1,24)$ that administration of milk or carbohydrate to infants with acute diarrhea results in increasing fecal loss of water. The stool water was often hyperosmotic to plasma, reaching values as high as $400 \mathrm{mOsm}$ per kg. Sugar and organic acids were the principal solutes in these stools, and again a reciprocal relation between the concentrations of those compounds and $\mathrm{NaCl}$ was found. Therefore, the characteristic changes in the composition of diarrheal stools that follow milk feeding are probably a reflection of impaired absorption of nonelectrolytes, such as the one herein described.

\section{Summary}

Electrolyte and glucose solutions of varying concentrations were perfused through a $25-\mathrm{cm}$ segment of proximal jejunum in normal infants and in those with diarrhea. Net fluxes of water, glucose, and electrolytes were determined under equilibrium conditions. Patients with diarrhea had impaired absorption of glucose (159 $\mu$ moles per minute; control infants, $351 \mu$ moles per minute). The net flux of water and salt was dependent upon the proportion of glucose absorbed. Thus, when the amount of nonabsorbed glucose was high, water and salt moved into the bowel. In the absence of glucose in the perfusate there was minimal net absorption of water and $\mathrm{NaCl}$ in both patients and controls. We suggest that net flux of water and $\mathrm{NaCl}$ into the jejunum is determined by the effective osmotic pressure exerted by unabsorbed solute. 


\section{References}

1. Torres-Pinedo, R., M. Lavastida, C. L. Rivera, H. Rodriguez, and A. Ortiz. Studies on infant diarrhea. I. A comparison of the effects of milk feeding and intravenous therapy upon the composition and volume of the stool and urine. J. clin. Invest. $1966,45,469$.

2. Weijers, H. A., J. H. van de Kamer, W. K. Dicke, and J. Ijsseling. Diarrhea caused by deficiency of sugar splitting enzymes. I. Acta paediat. (Uppsala) 1961, 50, 55.

3. Sunshine, P., and N. Kretchmer. Studies of small intestine during development. III. Infantile diarrhea associated with intolerance to disaccharides. Pediatrics 1964, 34, 38.

4. Holzel, A., V. Schwarz, and K. W. Sutcliffe. Defective lactose absorption causing malnutrition in infancy. Lancet 1959, 1, 1126.

5. Holzel, A., T. Mereu, and M. L. Thomson. Severe lactose intolerance in infancy. Lancet 1962, 2, 1346.

6. Clarke, J. T., W. Quillian, and H. Shwachman. Chronic diarrhea and failure to thrive due to intestinal disaccharidase insufficiency. Pediatrics 1964, $34,807$.

7. Bowie, M. D., G. L. Brinkman, and J. D. L. Hansen. Acquired disaccharide intolerance in malnutrition. J. Pediat. 1965, 66, 1083.

8. Burke, V., K. R. Kerry, and C. M. Anderson. The relationship of dietary lactose to refractory diarrhea in infancy. Aust. paediat. J. 1965, 1, 147.

9. Klotz, A. Intestinal lactase deficiency and diarrhea in adults. Amer. J. dig. Dis. 1964, 9, 345.

10. Lindquist, B., G. W. Meeuwisse, and K. Melin. Glucose-galactose malabsorption. Lancet 1962, 2, 666.

11. Lindquist, B., and G. W. Meeuwisse. Chronic diarrhoea caused by monosaccharide malabsorption. Acta paediat. (Uppsala) 1962, 51, 674.

12. Lindquist, B., G. Meeuwisse, and K. Melin. Osmotic diarrhoea in genetically transmitted glurosegalactose malabsorption (abstract). Acta paediat. (Uppsala) 1963, 52, 217.
13. Schneider, A. J., W. B. Kinter, and C. E. Stirling. Glucose-galactose malabsorption. Report of a case with autoradiographic studies of a mucosal biopsy. New Engl. J. Med. 1966, 274, 305.

14. Hirsch, J., E. H. Ahrens, Jr., and D. H. Blankenhorn. Measurement of the human intestinal length in vivo and some causes of variation. Gastroenterology 1956, 31, 274.

15. Roe, J. H., J. H. Epstein, and N. P. Goldstein. A photometric method for the determination of inulin in plasma and urine. J. biol. Chem. 1949, 178, 839.

16. Hydén, S. A turbidimetric method for the determination of higher polyethylene glycols in biological materials. Kungl. Lantbrurshogskolans annaler 1955, 22, 139.

17. Krebs, H. A., D. A. H. Bennet, P. de Gasquet, T. Gascoyne, and T. Yoshida. Renal gluconeogenesis. The effect of diet on the gluconeogenic capacity of rat-kidney-cortex slices. Biochem. J. 1963, 86, 22.

18. Fordtran, J. S., F. C. Rector, Jr., M. F. Ewton, N. Soter, and J. Kinney. Permeability characteristics of the human small intestine. J. clin. Invest. 1965, 44, 1935.

19. Staverman, A. J. The theory of measurement of osmotic pressure. Rec. Trav. chim. (Pays-Bas) 1951, 70, 344.

20. Kedem, O., and A. Leaf. The relation between salt and ionic transport coefficients. J. gen. Physiol. 1966, 49, 655.

21. Kedem, O., and A. Katchalsky. A physical interpretation of the phenomenological coefficients of membrane permeability. J. gen. Physiol. 1961, 45, 143.

22. Abbott, W. O., W. G. Karr, and T. G. Miller. Intubation studies of the human small intestine. VII. Factors concerned in absorption of glucose from the jejunum and ileum. Amer. J. dig. Dis. Nutr. 1937-38, 4, 742.

23. Curran, P. F., and G. F. Schwartz. Na, Cl, and water transport by rat colon. J. gen. Physiol. 1960, 43, 555 .

24. Torres-Pinedo, R. Unpublished observations. 